
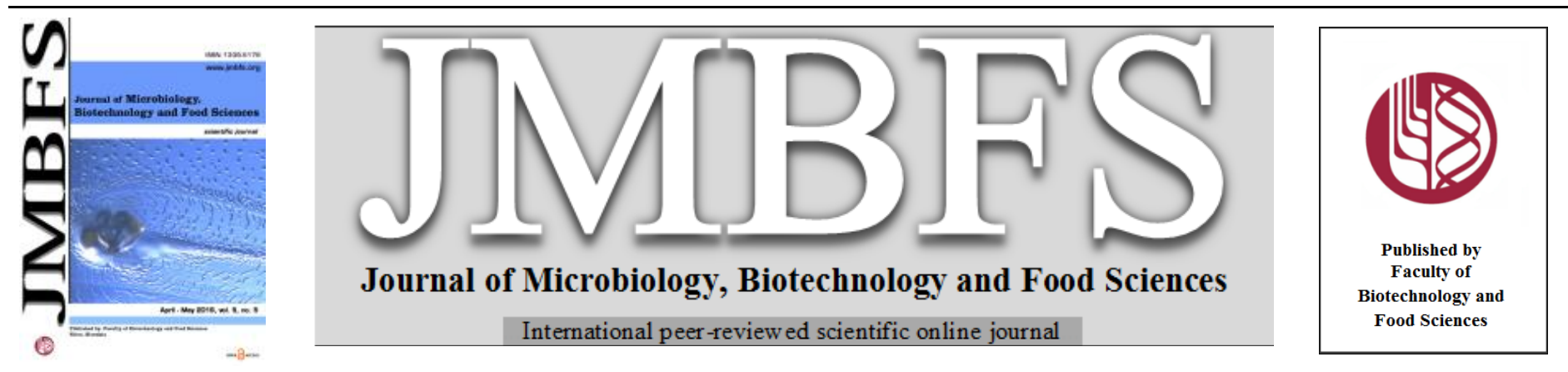

\title{
MODIFICATION OF PLA FOIL SURFACE BY ETHYLCELLULOSE AND ESSENTIAL OILS
}

\author{
Paweł Kwiatkowski*', Stefania Giedrys-Kalemba ${ }^{1,2}$, Małgorzata Mizielińska ${ }^{3}$, Artur Bartkowiak ${ }^{3}$
}

Address(es): Paweł Kwiatkowski, MSc.

${ }^{1}$ Department of Microbiology and Immunology, Pomeranian Medical University, Powstańców Wlkp. Avenue 72, 70-111 Szczecin, Poland.

${ }^{2}$ ALAB Laboratories Ltd., Stępińska Street 22/30, 00-739 Warsaw, Poland.

${ }^{3}$ Center of Bioimmobilisation and Innovative Packaging Materials, West Pomeranian University of Technology, Klemensa Janickiego Street 35, 71-270 Szczecin, Poland.

*Corresponding author: pawel.kwiatkowski@ pum.edu.pl

doi: 10.15414/jmbfs.2016.5.5.440-444

\section{ARTICLE INFO}

Received 6. 7. 2015

Revised 10. 12. 2015

Accepted 22. 1. 2016

Published 1. 4. 2016

Regular article

open $\bigodot_{\text {ACCESS }}$

\section{ABSTRACT}

The increasing consumer demand for safety and long-term products motivates the packaging industry to produce antimicrobial packaging. The task of the antimicrobial packaging is not only the inhibition of growth of the pathogenic microflora, but also the maintenance of sensory characteristics of the product for a long time. The aim of the study was to evaluate antimicrobial properties of modified PLA foils against Gram-positive and Gram-negative bacteria. Biodegradable PLA foils were covered 10\% ethylcellulose (EC) as carrier and commercial essential oils from fennel, rosemary and caraway as active substances. Antimicrobial properties were tested against Escherichia coli (Gram-negative) and Staphylococcus aureus (Gram-positive). The study was conducted using the American method ASTM E 2180-01. The results of experiments showed that modified essential oils PLA foils reduced the amount of Grampositive and Gram-negative bacteria. The best antibacterial properties would have PLA foil coating $10 \% \mathrm{EC}$ with $50 \mathrm{mg} / \mathrm{dm}^{2}$ of fennel essential oil.

Keywords: Escherichia coli, Staphylococcus aureus, PLA, essential oils

\section{INTRODUCTION}

Packages materials made from synthetic polymers are commonly used in the packaging industry. They show excellent properties such as high liquid and vapor barrier (especially in the case of composite materials) or good mechanical properties. However, one of the drawbacks is the lack of susceptibility to biodegradation (Szumigaj et al., 2008). Therefore, potentially dangerous plastics are very often being replaced with eco-friendly materials. One of the most popular representatives of biopolymers is a polylactide (PLA), which is decomposed into water and carbon dioxide. This polymer can be easily processed, and it is not toxic to higher organisms (Nowak \& Pająk, 2010) Unfortunately, the PLA also has many drawbacks (Nampoothiri et al., 2010). It is known that due to the high gas permeability, the polymer is often used for packaging food products with short time validity and flowers (Ambrosio-Martin et al., 2014). A solution of this problem may be covering PLA with coatings that improve the barrier properties against gases. The coatings may also have antimicrobial properties, which will increase the attractiveness of the PLA as a packaging material. The development of natural antimicrobial coatings, leading to active packaging, may be uncompromising achievement, significantly affecting the quality of the packaged goods, among other foodstuffs and flowers. Coatings containing active substances can be divided into those that migrate into the packaged product and those that do not (LaCoste $\boldsymbol{e t}$ al., 2005). The active compounds should inhibit the growth of microorganisms responsible for spoilage of packaged products and pathogenic microorganisms. The task of the active packaging is not only inhibiting the growth of pathogenic microflora, but also maintaining the sensory characteristics of the product for a long time.

Active packaging containing essential oils and spices extracts have antimicrobial properties against many bacteria and fungi (Sahari \& Asgari, 2013). Their natural components include antimicrobial phenolic compounds, aldehydes, ketones, alcohols, ethers and hydrocarbons (Hyldgaard et al., 2012; Kalemba \& Kunicka, 2003). The suitable concentration of the essential oil inhibiting microbial growth influences the quality of active packaging. The packaging containing essential oils as active ingredients exhibit a broad range of applications in the food industry (Sadaka et al., 2014).

Essential oils such as rosemary (Rosmarinus officinalis L.), caraway (Carum carvi L.) and fennel (Foeniculum vulgare Mill.) have shown antibacterial and antifungal activity (Begum et al., 2008; Diao et al., 2014; Jalali-Heravi et al.,
2011). Rosemary oil also possesses analgesic, anti-inflammatory, anti-oxidative, anti-tumor, anti-ulcerogenic and hepatoprotective properties (Minaiyan et al., 2011). The volatile oils from $C$. carvi have also been used as an anti-ulcerogenic, anti-tumor, anti-proliferative and anti-hyperglycemic agent (Thippeswamy et al., 2013). Fennel essential oil has shown anti-oxidant, cytotoxic, anti-inflammatory, hypotensive, hepatoprotective, anti-thrombotic and anti-mutagenic activity (Rahimi \& Ardekani, 2013). These oils are used in many industries and in natural medicine. The antimicrobial properties of essential oils are strictly connected with their chemical composition. The rosemary essential oil composition was dominated by 1.8 -cineole and camphor, followed by $\alpha$-pinene, $\beta$-pinene and $\beta$-cariophyllene (Aouadi et al., 2014). Caraway fruits contain a several components. Carvone, limonene, germacrene D and transdihydrocarvone are the main components available in their essential oil (Darougheh et al., 2014). Important compounds of the fennel essential oil are mainly trans-anethole, estragole and fenchone. Also, fennel oil contains trace amounts of other compounds including $\alpha$-pinene, limonene, $\beta$-pinene, $\beta$-myrcene, and p-cymene (Gori et al., 2012).

Staphylococcus aureus and Escherichia coli are two opportunistic pathogens that are responsible for moderate to severe and life-threatening infections. S. aureus is also a worldwide cause of food-borne infections (Fleurot $\boldsymbol{e t}$ al., 2014). These bacteria produce toxins which are responsible for staphylococcal food poisoning (Argudin et al., 2010). E. coli is present in human and animal intestine. Pathogenic strains are responsible for intestinal disorders e.g. diarrhea and extraintestinal infections in both humans and animals including urinary tract infections (UTI), septicemia and meningitis (Jafari et al., 2012).

The aim of the study was to examine the antibacterial activities of modified PLA foil surface by $10 \%$ ethylcellulose (EC) and commercial essential oils (rosemary, caraway and fennel) against representatives Gram-positive (S. aureus) and Gramnegative $(E$. coli) bacteria. Antibacterial properties was evaluated according to the European Norm ASTM E2180-07 (2012) for polymeric materials.

\section{MATERIAL AND METHODS}

Bacterial strains, media and growth condition

S. aureus (DSMZ 346) and E. coli (DSMZ 1576) were obtained from the Deutsche Sammlung von Mikroorganismen und Zellkulturen (GmbH, Germany). 
E. coli were cultivated on MacConkey agar (Merck KGaA, Germany) at $37^{\circ} \mathrm{C}$ for $24 \mathrm{~h}, \mathrm{~S}$. aureus on trypticase soy agar (TSA) (Merck KGaA, Germany) containing $10 \%$ sodium chloride (Sigma-Aldrich, Poland) at $37^{\circ} \mathrm{C}$ for $24 \mathrm{~h}$.

\section{PLA foil and essential oils}

PLA foil used in the study was embossed in Center of Bioimmobilisation and Innovative Packaging Materials with a thickness of $50 \mu \mathrm{m}$. The foil was cut into sheets of A4, coated with essential oil and sterilized under a UV lamp after $1 \mathrm{~h}$ on each side. Rosemary oil ( $R$. officinalis L.), caraway oil (C. carvi L.) and fennel oil (F. vulgare Mill.) used in this study were obtained from Vera-Nord Company, Poland (commercial producers of plant essential oils and aromatic substances) Quality of the oils was ascertained to be more than $98 \%$ pure. The oils exhibited a strong and characteristic odor.

\section{Coating PLA foil}

The essential oils were poured into beakers and weighed. To obtain relative concentrations of the extracts, $10 \%$ EC dissolved in $96 \%$ ethyl alcohol (SigmaAldrich, Poland) was added. To each beaker $0.5 \%$ (w/w) Tween 20 (Scharlau Chemie S.A., Spain) was added and stirred until a uniform distribution of the oils in EC. 5\% solutions of essential oils were prepared in the carrier - EC. Coater (Unicoater 409, Erichsen, Germany) equipped with a roller with a diameter of $1.27 \mathrm{~mm}$ wire was used to apply coating to the sheets of PLA foil. The foils were then dried for $15 \mathrm{~min}$ at $55^{\circ} \mathrm{C}$. Layer of suitable thickness was obtained. The content of active substance in the coating to the foil surface was calculated using equation from ASTM E 2180-07 (2012)

$$
A=X[\%] \times G[\mu \mathrm{m}] \times 0,01 \times 1000\left[\mathrm{mg} / \mathrm{dm}^{2}\right]
$$

where $A$ is the content of active substance in the coating relative to the foil surface, $X$ is the percentage of the active substance in an amount applied to the foil sheet, and $G$ is the thickness of the deposited foil

It was prepared 5 tested foils: 3 coated different oils and 2 controls, which was cut for 6 squares $(3 \times 3 \mathrm{~cm})$. Controls were: pure PLA (foil $\mathrm{nr} 1 *$ ) and PLA $+10 \%$ $\mathrm{EC}$ (foil nr 2*).

\section{Attenuated total reflectance FT-IR PLA foil}

Examination of the foil surface structure was performed with using infrared spectrometry with Fourier transform by attenuated total reflectance (ATR FT-IR). Two samples were used: pure PLA foil and PLA foil coated with $10 \%$ EC. Infrared spectra were studied in the wavelength range of the radiation 4000-600 $\mathrm{cm}^{-1}$ with a number of four scans per sample. The tests were performed on both inner and outer side of PLA foil. In order to compare the spectra obtained with the spectrum of reference materials substance spectra library was searched.

The presence of the coating was also observed with a scanning electron microscope (SEM) Vega 3 LMU (Tescan, Czech Republic).

\section{Antibacterial activity of coated PLA foils}

The antimicrobial properties of coated PLA foil were studied with using reference method ASTM E 2180-07 (2012), which is exploited for the establishment of a research activity antimicrobial agent(s) incorporated into the polymeric or hydrophobic materials.

From reference bacterial strains cultivated $24 \mathrm{~h}$ at $37^{\circ} \mathrm{C}$ on agar media (MacConkey - E. coli, TSA - S. aureus) solutions $1.5 \times 10^{8}$ cells $/ \mathrm{ml}$ of $0.9 \%$ $\mathrm{NaCl}$ concentration were prepared with using McFarland scale turbidity. $1 \mathrm{ml}$ of this suspensions was added to $100 \mathrm{ml}$ of $0.3 \%$ TSA medium at a temp. of $45^{\circ} \mathrm{C}$ to obtain $1.5 \times 10^{6}$ cells $/ \mathrm{ml}$ suspension. Next $1 \mathrm{ml}$ of $1.5 \times 10^{6}$ cells $/ \mathrm{ml}$ bacterial suspension was gently inoculated on the earlier prepared foil samples, which were placed on Petri dishes with $90 \mathrm{~mm}$ diameter. The Petri dishes were inserted into the climate chamber at $37^{\circ} \mathrm{C}$ and humidity of $90 \%$. After $24 \mathrm{~h}$, the samples were transferred from plates to falcons containing $30 \mathrm{ml}$ of trypticase soy broth (TSB) (Merck KGaA, Germany) and stirred for $1 \mathrm{~min}$. Next have taken $200 \mu \mathrm{l}$ of TSB suspension, prepared serial dilutions, inoculated on Petri dishes with TSA and incubated for $24 \mathrm{~h}$ at $37^{\circ} \mathrm{C}$. After incubation colonies were counted using colony counter (Ika2002 POL-EKO, Poland) and their average values (of three repeats) were tabulated. Countable colonies were found in dilution of $10^{-3}$ for $S$. aureus and $10^{-6}$ for E. coli.

\section{Statistical analysis}

All experiments were performed in triplicate. The mean and standard deviation of at least three experiments were determined using Microsoft Excel 2010 (Micrososoft Corporation, USA).

\section{RESULTS AND DISCUSSION}

In recent decades, interest in essential oils, which are used for centuries in natural medicine, increased. Many essential oils are claimed to possess antimicrobia activity and they have been used for the prevention and treatment of many infectious diseases as alternative remedies. It is known that the efficacy of the essential oil depends on many environmental and genetic factors. It has been proven that the main factors responsible for the diverse chemical composition of essential oils are climatic conditions, geographic origin, time of collection, distillation conditions, correct farming practices and part of the plant from which oil is extracted (Aćimović et al., 2014; Fernández et al., 2014; Msaada et al., 2007). In our study commercial essential oils derived from rosemary, caraway and fennel were used. These oils did not have a precise characteristic all the factors influencing on bactericidal activity but they are used in aromatherapy, aromatization of premises, rubbing, sauna, bath or shower.

\section{Content of active substances in coated PLA foils}

The content of active substances was calculated using Eqn. 1. Foils nr $3^{*}-5^{*}, 100$ $\mu \mathrm{m}$ thickness $(G)$ were coated with $5 \%$ of each active substances $(X)$. The content of active substance in the coating relative to the foil surface was $50 \mathrm{mg} / \mathrm{dm}^{2}(A)$ Table 1

Table 1 The content of active substance coated PLA foils

\begin{tabular}{lcccc}
\hline Number of foil & $\begin{array}{c}\text { The diameter of the wire } \\
{[\mathbf{m m}]}\end{array}$ & $\begin{array}{c}\boldsymbol{X} \\
{[\%]}\end{array}$ & $\begin{array}{c}\boldsymbol{G} \\
{[\boldsymbol{\mu m}]}\end{array}$ & $\begin{array}{c}\boldsymbol{A} \\
{\left[\mathbf{m g} / \mathbf{d m}^{2}\right]}\end{array}$ \\
\hline $1^{*}$ & - & - & - & - \\
\hline $2^{*}$ & 1.27 & - & 100 & - \\
\hline $3^{*}$ & 1.27 & 5 & 100 & 50 \\
\hline $4^{*}$ & 1.27 & 5 & 100 & 50 \\
\hline $5^{*}$ & 1.27 & 5 & 100 & 50 \\
\hline
\end{tabular}

Legend: $1 *$ - pure PLA foil (control sample), $2 *$ - PLA foil + 10\% EC (control sample), 3 - PLA foil $+10 \%$ EC $+5 \%$ caraway oil, $4 *-$ PLA foil $+10 \%$ EC $+5 \%$ rosemary oil, $5 *-$ PLA foil $+10 \% \mathrm{EC}+5 \%$ fennel oil

\section{Analysis of modified PLA foils using ATR FT-IR}

Spectroscopy analysis using ATR FT-IR was performed on both sides of two samples of PLA foils: pure and coated with $10 \%$ EC. Experiments have shown that both the pure PLA foil and modified $10 \%$ EC do not have impurities that could adversely affect the microorganisms. Results of the obtained spectrum shown no significant differences in the peaks. Thus proving that pure PLA foil did not contain substances that could indicate the pollution (Figure 1). Experiments have also confirmed that the spectrum of PLA foil with $10 \%$ EC content coincided with the spectrum of pure PLA foil (Figure 2). Therefore, also been proving that $10 \%$ EC coating on the surface of PLA foil did not cause adverse chemical changes of the biopolymer. Analysis of the obtained spectra of pure PLA foil and the uncoated surface of the modified PLA foil with using a library of spectra showed $99 \%$ similarity. The spectrum of $10 \%$ EC modified PLA foil was characterized by the greatest degree of match to the spectrum of the standard (pure PLA foil) equal to $94 \%$ (Figure 3).

SEM analysis of coated and pure PLA foil confirmed the presence of the coating film on the surface of PLA foil (Figure 4), proving the fact that the EC, due to good adhesion to the foil surface, was properly selected carrier. Shell did not undergo separation from the surface of the PLA and did not break. 


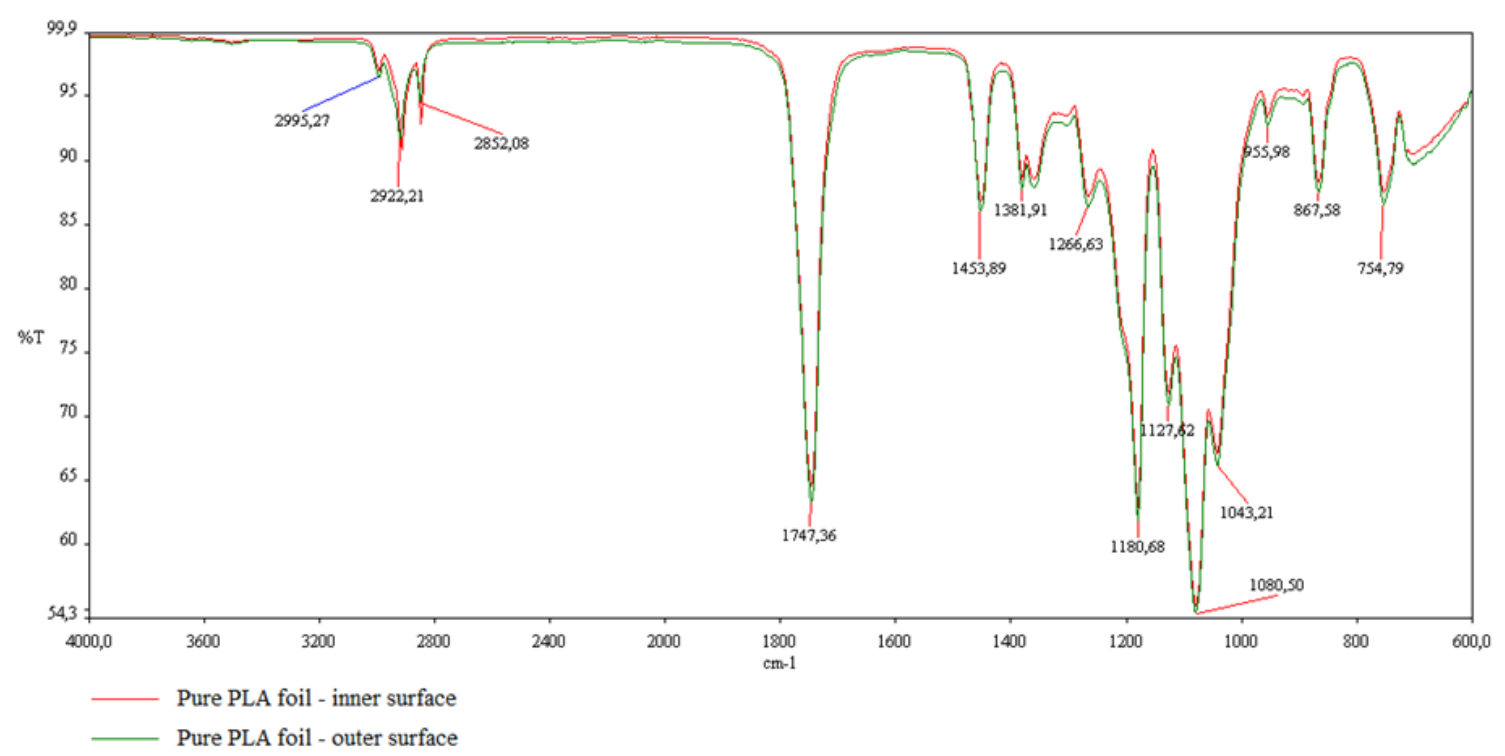

Figure 1 ATR FT-IR spectra of pure PLA foil measured on the two surface sides

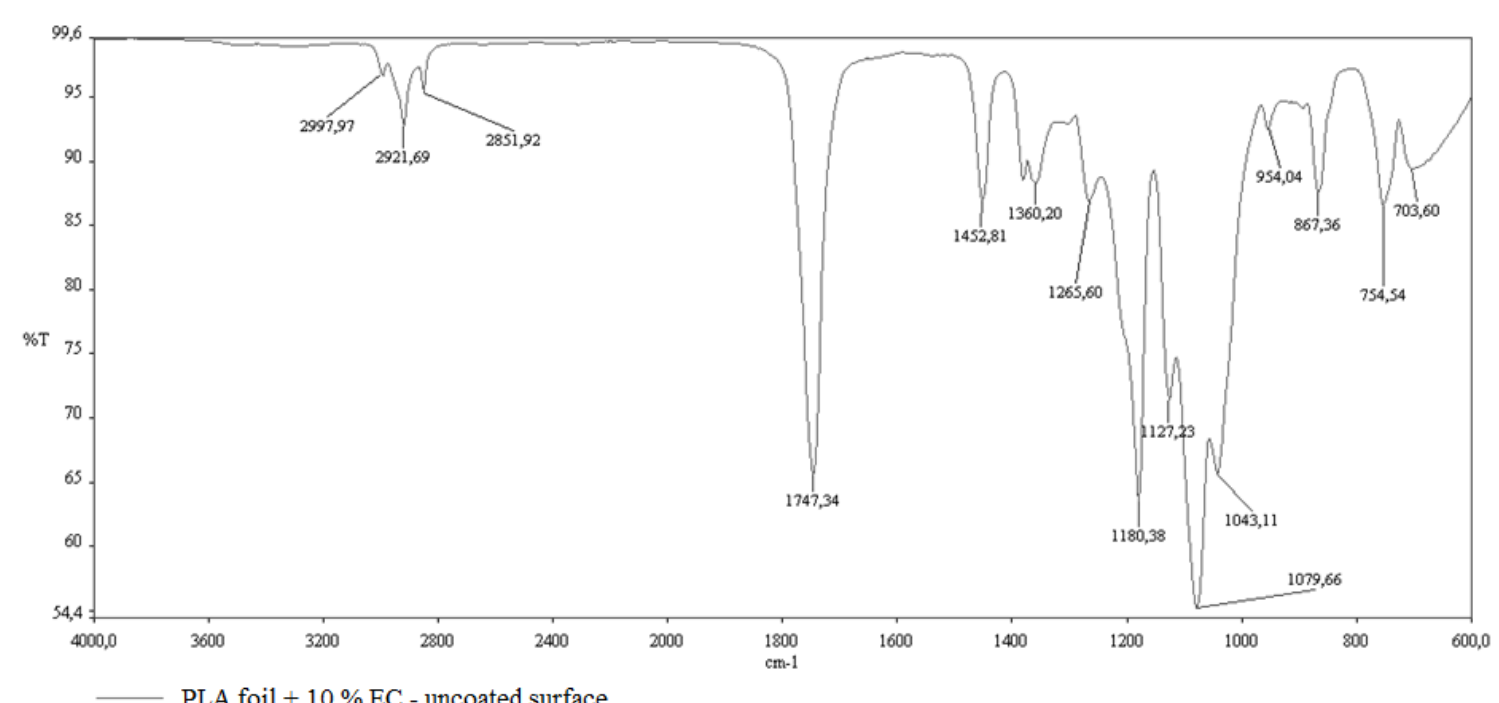

Figure 2 ATR FT-IR spectra of the modified PLA foil with 10\% EC - uncoated surface

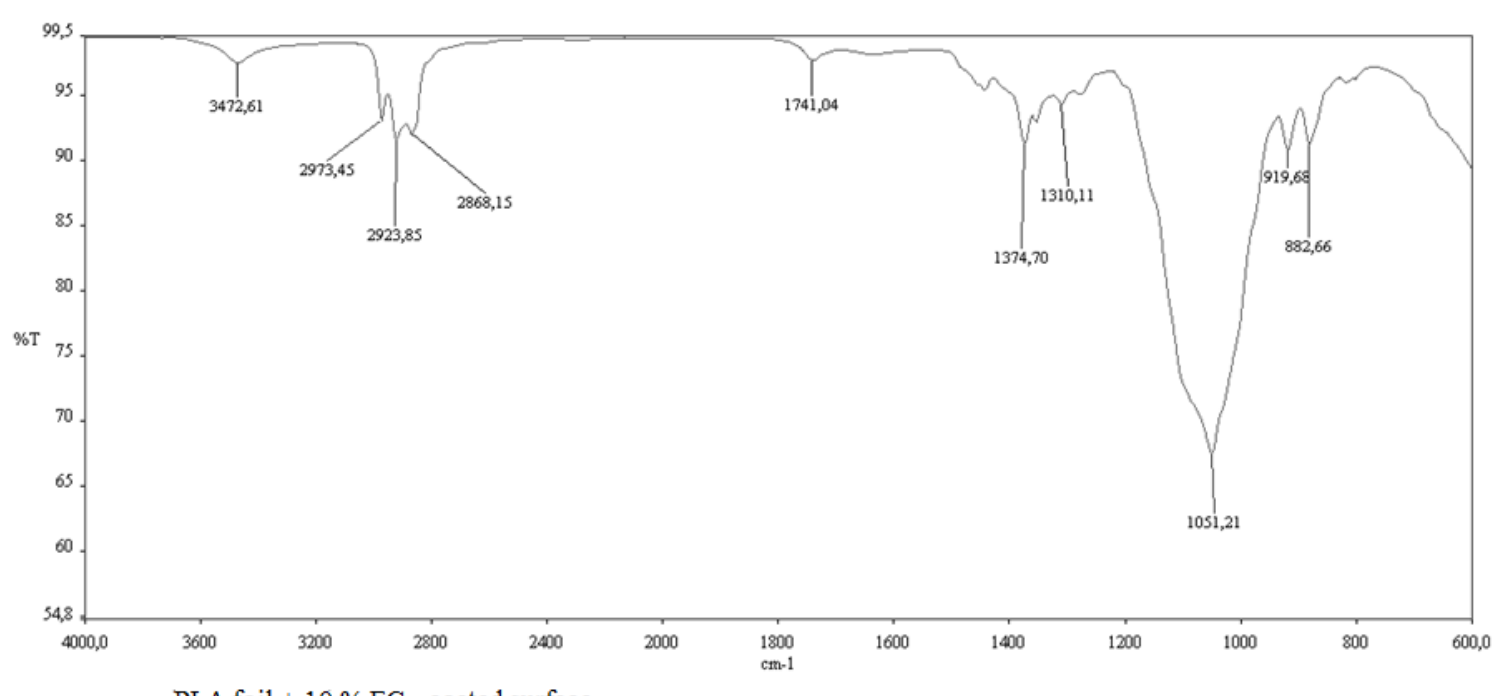

PLA foil $+10 \%$ EC - coated surface

Figure 3 ATR FT-IR spectra of the modified PLA foil with 10\% EC - coated surface 


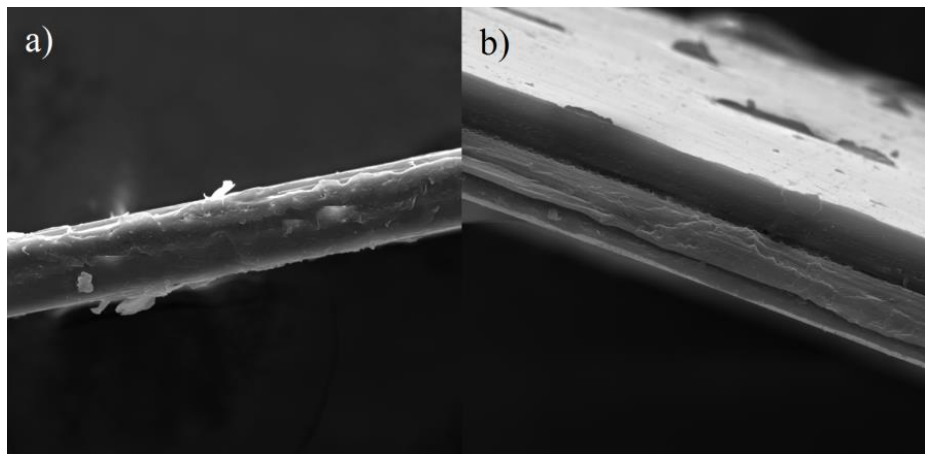

Figure 4 SEM picture of PLA foil surface: a) control, b) coated 10\% EC

The antimicrobial properties of the coated PLA foils

According to Jamshidian et al. (2010) the innovative strength of PLA antimicrobial packaging has a direct impact on consumer health by creating safer and more wholesome packaged foods. Lopez-Rubio et al. (2006) claims that the most common and considered for novel bioactive packaging include antimicrobials, vitamins, phytochemicals, prebiotics, marine oils, and immobilized enzymes. In our study coating with $10 \% \mathrm{EC}$ as a carrier and commercial essential oils (caraway oil, rosemary oil and fennel oil) as active substance were produced. It was found that $10 \% \mathrm{EC}$ had a minor effect on the growth of S. aureus. The decrease of bacterial cells was $8.53 \%$ due to the effect of the pure PLA foil (Table 2, Figure 5). The study showed that foils containing active essential oils have similar antibacterial properties against $S$. aureus. The best properties reducing Gram-positive bacteria had fennel oil (85.36\%), next rosemary oil $(84.74 \%)$ and caraway oil $(81.08 \%)$ - no significant differences (Table 2, Figure 5).

Table 2 Influence of coatings containing essential oils on the number of $S$. aureus cells

\begin{tabular}{lcccc}
\hline Number of foil & $\begin{array}{c}\boldsymbol{X} \\
{[\%]}\end{array}$ & $\begin{array}{c}\boldsymbol{G} \\
{[\boldsymbol{\mu \mathrm { m } ]}]}\end{array}$ & $\begin{array}{c}\boldsymbol{A} \\
{\left[\mathbf{m g} / \mathbf{d m}^{2}\right]}\end{array}$ & $\begin{array}{c}\text { The amount of } \\
\text { bacterial cells } \\
{[\mathbf{c f u} / \mathbf{m l}]}\end{array}$ \\
\hline $1^{*}$ & - & & - & $27.33 \pm 4.65$ \\
\hline $2^{*}$ & - & 100 & - & $25 \pm 4.36$ \\
\hline $3^{*}$ & 5 & 100 & 50 & $5.17 \pm 1.26$ \\
\hline $4^{*}$ & 5 & 100 & 50 & $4.17 \pm 1.04$ \\
\hline $5^{*}$ & 5 & 100 & 50 & $4 \pm 0.5$ \\
\hline
\end{tabular}

Legend: *1 - pure PLA foil (control sample), $2 *$ - PLA foil + 10\% EC (control sample), $3 *$ PLA foil $+10 \%$ EC $+5 \%$ caraway oil, $4 *-$ PLA foil $+10 \%$ EC $+5 \%$ rosemary oil, $5 *$ PLA foil $+10 \%$ EC $+5 \%$ fennel oil

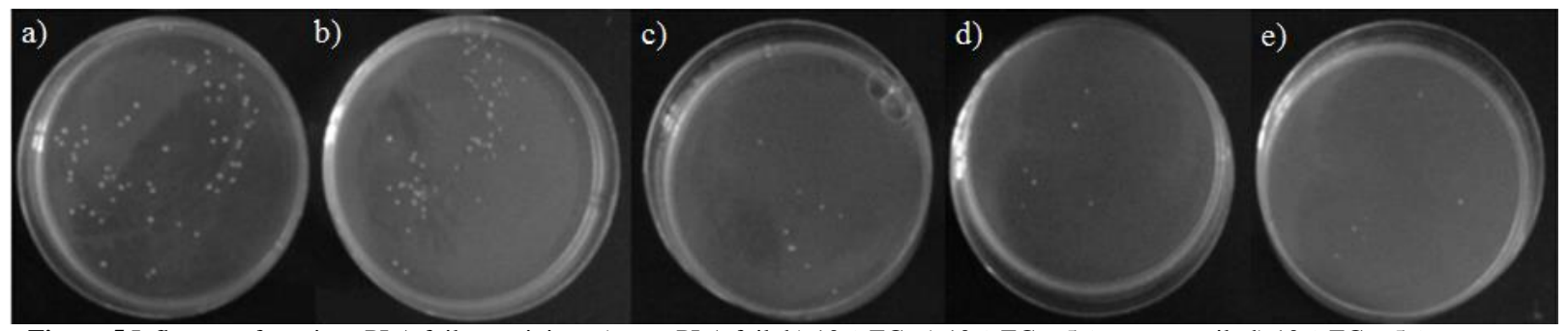

Figure 5 Influence of coatings PLA foil containing: a) pure PLA foil, b) 10\% EC, c) $10 \%$ EC + 5\% caraway oil, d) $10 \%$ EC + 5\% rosemary oil, e) $10 \% \mathrm{EC}+5 \%$ fennel oil to reduce the number of $S$. aureus cells

The antibacterial effect of the active foils to E. coli was weaker. $10 \%$ EC reduces the amount of bacterial cells by $18.48 \%$ in comparison to pure foil (Table 3 , Figure 6). Foils containing active essential oils have similar antibacterial properties against $E$. coli. The reduction of the number of microbial cells was $70 \%$ for fennel oil, $69.01 \%$ for rosemary oil and $66.5 \%$ for caraway oil (Table 3 , Figure 6).
Table 3 Influence of coatings containing essential oils on the number of $E$. coli cells

\begin{tabular}{ccccc}
\hline $\begin{array}{c}\text { Number of } \\
\text { foil }\end{array}$ & $\begin{array}{c}\boldsymbol{X} \\
{[\boldsymbol{\%}]}\end{array}$ & $\begin{array}{c}\boldsymbol{G} \\
{[\boldsymbol{\mu m}]}\end{array}$ & $\begin{array}{c}\boldsymbol{A} \\
{\left[\mathbf{m g} / \mathbf{d m}^{2}\right]}\end{array}$ & $\begin{array}{c}\text { The amount of } \\
\text { bacterial cells } \\
{[\mathbf{c f u} / \mathbf{m l}]}\end{array}$ \\
\hline 1 & - & & - & $33.33 \pm 3.25$ \\
\hline 2 & - & 100 & - & $27.17 \pm 2.02$ \\
\hline 3 & 5 & 100 & 50 & $11.17 \pm 2.57$ \\
\hline 4 & 5 & 100 & 50 & $10.33 \pm 3.25$ \\
\hline 5 & 5 & 100 & 50 & $10 \pm 1.32$ \\
\hline
\end{tabular}

Legend: $1 *$ - pure PLA foil (control sample), $2 *$ - PLA foil + 10\% EC (control sample), 3* - PLA foil $+10 \% \mathrm{EC}+5 \%$ caraway oil, $4 *-$ PLA foil $+10 \% \mathrm{EC}+5 \%$ rosemary oil, $5^{*}$ PLA foil $+10 \%$ EC $+5 \%$ fennel oil

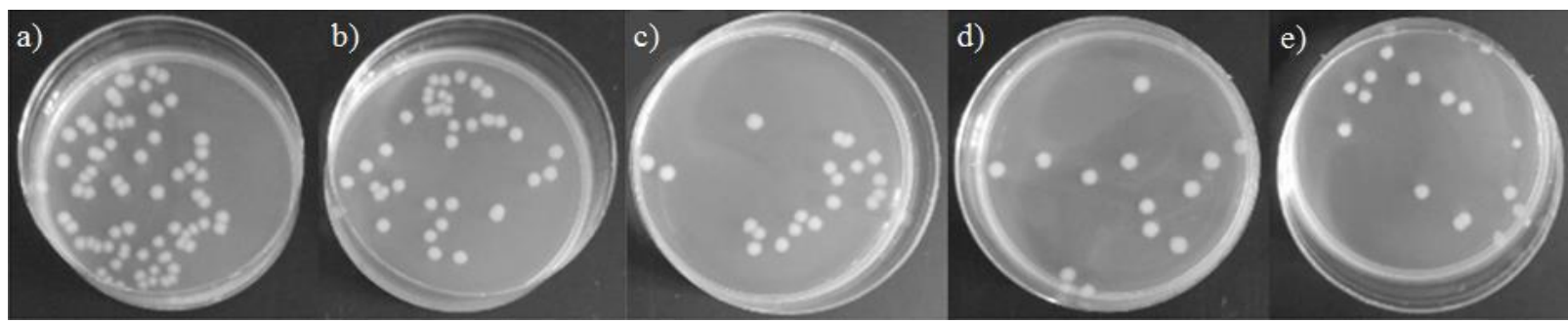

Figure 6 Influence of coatings PLA foil containing: a) pure PLA foil, b) $10 \%$ EC, c) $10 \%$ EC + 5\% caraway oil, d) $10 \%$ EC + 5\% rosemary oil, e) $10 \% \mathrm{EC}+5 \%$ fennel oil to reduce the number of $E$. coli cells

The topic of the antimicrobial properties of PLA foil containing active substances have been analyzed by other authors as well. The thermoplastic starch chitosan diffusion process to the substrate in conjunction with polylactide was studied (Bie $\boldsymbol{e t}$ al., 2013). The authors investigated the effect of analyzed substance mixtures on the growth of $E$. coli and $S$. aureus. It has been shown the addition of thermoplastic starch in the matrix enhanced the hydrophilicity of PLA blend, which preferably affects the diffusion of chitosan to the medium. Starch improves dynamic contact angle of the active substance. In addition, a blend consisting of $36 \%$ thermoplastic starch, 54\% PLA and $10 \%$ of chitosan significantly reduced the number of cells of $E$. coli and $S$. aureus. Other scientists demonstrated antimicrobial properties of PLA foil coated cinnamaldehyde, which is unsaturated aldehyde naturally present in essential oils (Makwana et al., 2014). They have found reduced the number of E. coli and Bacillus cereus. The Gram-positive bacilli were more sensitive to the active oil substances than Gram- negative rods. These results correspond with our results, which proved that also more sensitive to the active essential oils coating on the surface of PLA foil were Gram-positive bacteria. Also Burt \& Reinders (2003) claim that the cell wall of Gram-negative bacteria is more resistant to the toxic effects of essential oils than Gram-positive bacteria. The structure of the Gram-positive bacteria cell wall allows hydrophobic molecules to easily penetrate to the cells (Nazzaro et al., 2013).

The study performed by Erdohan et al. (2013) shown that olive leaf extract (Olea europaea) located in the coating on the surface of PLA foil has antibacterial activity against $S$. aureus. The authors found that the increase of active substance on PLA foil from $0.9 \mathrm{mg}$ to $5.4 \mathrm{mg}$ increases a zone of bacterial growth inhibition from $9.1 \mathrm{~mm}$ to $16.2 \mathrm{~mm}$. Seydim \& Sarikus (2006) proved that whey protein based edible foils incorporated with oregano, rosemary and garlic essential oils had antimicrobial activity against S. aureus, Salmonella Enteritidis, Listeria monocytogenes and E. coli. López et al. (2007) shown 
the antimicrobial activity of polypropylene and polyethylene/ethylene vinyl alcohol copolymer incorporating essential oil of cinnamon, oregano, clove or cinnamon fortified with cinnamaldehyde against a wide range of microorganisms.

\section{CONCLUSION}

Our results confirmed that commercial essential oils coated modified $10 \%$ EC PLA foils cause significant growth inhibiting effects on Gram-positive ( $S$. aureus) and Gram-negative (E. coli) bacteria and have similar antimicrobial properties as essential oils obtained from plants in the laboratory condition. In this study we used a standard strain of S. aureus DSMZ 346 (known as strain P209) and standard strain of E. coli DSMZ 1576 (known as Crooks). The efficiency of rosemary, caraway and fennel essential oils against the representatives of most important human pathogens provides a scientific ground for future. Experiments indicate that $10 \% \mathrm{EC}$ is an effective carrier of active substances used to create antimicrobial coatings. In summary the packaging materials produced using such coatings could protect food against undesirable microorganisms including pathogens. The best antibacterial properties would have PLA foil coating $10 \%$ EC with $50 \mathrm{mg} / \mathrm{dm}^{2}$ fennel essential oil.

Acknowledgments: The first author gratefully acknowledges Center of Bioimmobilisation and Innovative Packaging Materials for help in the conduct the experiments for a master's thesis.

\section{REFERENCES}

AĆIMOVIĆ, M.G., OLJAČA, S.I., TEŠEVIĆ, V.V., TODOSIJEVIĆ, M.M., DJISALOV, J.N. 2014. Evaluation of caraway essential oil from different production areas of Serbia. Horticultural Science (Prague), 41, 122-130.

AMBROSIO-MARTIN, J., FABRA, M.J., LOPEZ-RUBIO, A., LAGARON, J.M. 2014. An effect of lactic acid oligomers on the barrier properties of polylactide. Journal of Material Science, 49, 2975-2986.

http://dx.doi.org/10.1007/s10853-013-7929-x

AOUADI, D., LUCIANO, G., VASTA, V., NASRI, S., BROGNA, D.M.R. ABIDI, S., PRIOLO, A., SALEM, H.B. 2014. The antioxidant status and oxidative stability of muscle from lambs receiving oral administration of Artemisia herba and Rosmarinus officinalis essential oils. Meat Science, 97, $237-$ 243. http://dx.doi.org/10.1016/j.meatsci.2014.02.005

ARGUDIN, M.Á., MENDOZA, M.C., RODICIO, M.R. 2010. Food poisoning and Staphylococcus aureus enterotoxins. Toxins, 2, 1751-1773.

http://dx.doi.org/10.3390/toxins2071751

ASTM E 2180-07. 2012. Standard test method for determining the activity of incorporated antimicrobial agent(s) in polymeric or hydrophobic materials, ASTM International, West Conshohocken, PA. http://dx.doi.org/10.1520/e2180 $\underline{07 \mathrm{r} 12}$

BEGUM, J., BHUIYAN, M.N.I., CHOWDHURY, J.U., HOQUE, M.N., ANWAR, M.N. 2008. Antimicrobial activity of essential oil from seeds of Carum carvi and its composition. Bangladesh Journal of Microbiology, 25, 8589. http://dx.doi.org/10.3329/bjm.v25i2.4867

BIE, P., LIU, P., YU, L., LI, X., CHEN, L., XIE, F. 2013. The properties of antimicrobial films derived from poly(lactic acid)/starch/chitosan blended matrix. $\begin{array}{llll}\text { Carbohydrate Polymers. } & 966 .\end{array}$ http://dx.doi.org/10.1016/j.carbpol.2013.07.004

BURT, S.A., REINDERS, R.D. 2003. Antibacterial activity of selected plant essential oils against Escherichia coli O157:H7. Letters in Applied Microbiology, 36, 162-167. http://dx.doi.org/10.1046/j.1472-765x.2003.01285.x

DAROUGHEH, F., BARZEGAR, M., SAHARI, M. A. 2014. Antioxidant and anti-fungal effect of caraway (Carum carvi L.) essential oil in real food system. $\begin{array}{llll}\text { Current Nutrition \& Food } & \text { Science, } & 10(1), & 70-76\end{array}$ http://dx.doi.org/10.2174/1573401310666140306004839

DIAO, W., HU, Q., ZHANG, H., XU, J. 2014. Chemical composition, antibacterial activity and mechanism of action of essential oil from seeds of fennel (Foeniculum vulgare Mill.). Food Control, 35, 109-116. http://dx.doi.org/10.1016/j.foodcont.2013.06.056

ERDOHAN, Z.Ö., CAM, B., TURHAN, K.N. 2013. Characterization of antimicrobial polylactic acid based films. Journal of Food Engineering, 119, 308-315. http://dx.doi.org/10.1016/j.jfoodeng.2013.05.043

FERNÁNDEZ, L.F., PALOMINO, O.M., FRUTOS, G. 2014. Effectiveness of Rosmarinus officinalis essential oil as antihypotensive agent in primary hypotensive patients and its influence on health-related quality of life. Journal of Ethnopharmacology, 151, 509-516.

http://dx.doi.org/10.1016/j.jep.2013.11.006

FLEUROT, I., AIGLE, M., FLEUROT, R., DARRIG, C., HENNEKINNE, J. GRUSS, A., BOREZÉE-DURANT, E., DELACROIX-BUCHET, A. 2014 Following pathogen development and gene expression in a food ecosystem: the case of a Staphylococcus aureus isolate in cheese. Applied and Environmental Microbiology, 18, 5106-5115. http://dx.doi.org/10.1128/aem.01042-14

GORI, L., GALlO, E., MASCHERINI, V., MUGELLI, A., VANNACCI, A., FIRENZUOLI F. 2012. Can estragole in fennel essential seed decoctions really be considered a danger for human health? A fennel safety update. Evidence- based Complementary and Alternative Medicine, 2012, 860542 http://dx.doi.org/10.1155/2012/860542

HYLDGAARD, M., MYGIND, T., MEYER, R.L. 2012. Essential oils in food preservation: mode of action, synergies, and interactions with food matrix components. Frontiers in Microbiology, 02, 1-24. http://dx.doi.org/10.3389/fmicb.2012.00012

JAFARI, A., ASLANI, M.M., BOUZARI, S. 2012. Escherichia coli: a brief review of diarrheagenic pathotypes and their role in diarrheal diseases in Iran. Iranian Journal of Microbiology, 4, 102-117.

JALALI-HERAVI, M., MOAZENI, R.S., SERESHTI, H. 2011. Analysis of Iranian rosemary essential oil: Application of gas chromatography-mass spectrometry combined with chemometrics. Journal of Chromatography A, 18, 2569-2576.

http://dx.doi.org/10.1016/j.chroma.2011.02.048

JAMSHIDIAN, M., TEHRANY, E.A., IMRAN, M., JACQUOT, M DESORBY, S. 2010. Poly-lactic acid: production, applications, nanocomposites, and release studies. Comprehensive Reviews in Food Science and Food Safety, 9, 552-571.

http://dx.doi.org/10.1111/j.1541-4337.2010.00126.x

KALEMBA, D., KUNICKA, A. 2003. Antibacterial and antifungal properties of essential oils. Current Medicinal Chemistry, 10: 813-829.

http://dx.doi.org/10.2174/0929867033457719

LACOSTE, A., SCHAICH, K.M., ZUMBRUNNEN, D., YAM, K.L. 2005 Advancing controlled release packaging through smart blending. Packaging Technology and Science, 18, 77-87. http://dx.doi.org/10.1002/pts.675

LOPEZ-RUBIO, A., GAVARA, R., LAGARON, J.M. 2006. Bioactive packaging: turning foods into healthier foods through biomaterials. Trends in Food Science and Technology, $\quad 17, \quad 567-575$. http://dx.doi.org/10.1016/j.tifs.2006.04.012

LÓPEZ, P., SÁNCHEZ, C., BATLLE, R., NERÍN, C. 2007. Development of flexible antimicrobial films using essential oils as active agents. Journal of Agricultural and Food Chemistry, 21, 8814-8824. http://dx.doi.org/10.1021/jf071737b

MAKWANA, S., CHOUDHARY, R., DOGRA, N., KOHLI, P., HADDOCK, J. 2014. Nanoencapsulation and immobilization of cinnamaldehyde for developing antimicrobial food packaging material. Food Science and Technology, 57, 470476.

http://dx.doi.org/10.1016/j.lwt.2014.01.043

MINAIYAN, M., GHANNADI, A.R., AFSHARIPOUR, M., MAHZOUNI, P. 2011. Effects of extract and essential oil of Rosmarinus officinalis L. on TNBSinduced colitis in rats. Research in Pharmaceutical Sciences, 6, 13-21.

MSAADA, K., HOSNI, K., TAARIT, M.B., CHAHED, T., KCHOUK, M.E., MARZOUK, M. 2007. Changes on essential oil composition of coriander (Coriandrum sativum L.) fruits during three stages of maturity. Food Chemistry 102, 1131-1134

http://dx.doi.org/10.1016/j.foodchem.2006.06.046

NAMPOOTHIRI, M.K., NAIR, N.R., JOHN, R.P. 2010. An overview of the recent developments in polylactide (PLA) research. Bioresource Technology, 101, 8493-8501. http://dx.doi.org/10.1016/j.biortech.2010.05.092

NAZZARO, F., FRATIANNI, F., DE MARTINO, L., COPPOLA, R., DE FEO, V. 2013. Effect of essential oils on pathogenic bacteria. Pharmaceuticals, 6 , 1451-1474. http://dx.doi.org/10.3390/ph6121451

NOWAK, B., PAJĄK, J. 2010. Biodegradation of poly(lactide) (PLA). Archives of Waste Management and Environmental Protection, 2, 1-10.

RAHIMI, R., ARDEKANI, M.R.S. 2013. Medicinal properties of Foeniculum Vulgare Mill. in traditional Iranian medicine and modern phytotherapy. Chinese Journal of Integrative Medicine, 19, 73-79. http://dx.doi.org/10.1007/s11655013-1327-0

SADAKA, F., NGUIMJEU, C., BRACHAIS, C.H., VROMAN, I., TIGHZERT, L., COUVERCELLE, J.P. 2014. Review on antimicrobial packaging containing essential oils and their active biomolecules. Innovative Food Science and Emerging Technologies, 1, 1-23.

http://dx.doi.org/10.1016/j.ifset.2013.01.004

SAHARI, M.A., ASGARI, S. 2013. Effects of plants bioactive compounds on foods microbial spoilage and lipid oxidation. Food Science and Technology, 1, $52-61$

SEYDIM, A.C., SARIKUS, G. 2006. Antimicrobial of activity of whey proteins based edible films incorporated with oregano rosemary and garlic essential oils. $\begin{array}{llll}\text { Food Research } & \text { International, } & 39, & 639-644\end{array}$ http://dx.doi.org/10.1016/j.foodres.2006.01.013

SZUMIGAJ, J., ŻAKOWSKA, Z., KLIMEK, L., ROSICKA-KACZMAREK, J., BARTKOWIAK, A. 2008. Assessment of polylactide foil degradation as a result of filamentous fungi activity. Polish Journal of Environmental Studies, 17, 335341

THIPPESWAMY, N.B., NAIDU, K.A., ACHUR, R.N. 2013. Antioxidant and antibacterial properties of phenolic extract from Carum carvi L. Journal of Pharmacy Research, 7, 352-357. http://dx.doi.org/10.1016/j.jopr.2013.03.028 